Jurnal Kejaora: Jurnal Kesehatan Jasmani dan Olah Raga

ISSN: 2541-5042 (Online)

ISSN: 2503-2976 (Print)

Volume 5 Nomor 2, Edisi November 2020

\title{
LATIHAN SPEED, AGILITY AND QUICKNESS (SAQ) UNTUK MENINGKATKAN KELINCAHAN PADA ATLET FUTSAL PUSLATCAB TAHUN 2020
}

\author{
Mohammad Hasan Basri¹, Noer Wahid Riqzal Firdaus² \\ 1,2 STKIP PGRI Sumenep \\ E-mail: moh_hasan_basri@stkippgrisumenep.ac.id'1, riqzal@stkippgrisumenep.ac.id² \\ DOI: https://doi.org/10.36526/kejaora.v5i2.1033
}

\begin{abstract}
ABSTRAK
Tujuan penelitian ini untuk mengaplikasikan program pelatihan speed agility and quickness ini pada atlet Futsal Kabupaten Sumenep. Jenis penelitian ini adalah eksperimen dengan rancangan penelitian randomized control group pretest-posttest design. Didalam penelitian eksperimen ada empat prinsip yang perlu diperhatikan, yaitu: subjek ditempatkan secara acak, adanya perlakuan, adanya kelompok kontrol, dan adanya ukuran keberhasilan. Teknik sampling yang digunakan dalam penelitian ini menggunakan metode matching pairing. Analisis data menggunakan uji t. Hasil penelitian menunjukkan adanya peningkatan kecepatan yang signifikan setelah diberi perlakuan selama enam minggu. Hal ini dapat dilihat dari rerata tes akhir sebesar 10,11 dan rerata tes awal sebesar 11,26 dengan standart devisiasi untuk pre-test sebesar 0,44 dan post-test sebesar 0,54. Sehingga selisih dari rerata tersebut menunjukkan adanya peningkatan setelah diberi perlakuan selama pelatihan delapan minggu dan dengan frekuensi tiga kali. Dengan demikian dapat disimpulkan bahwa setelah adanya perlakuan selama enam mingggu dengan program pelatihan speed, agility and quickness (SAQ) dapat memberikan dampak peningkatan kelincahan sebesar $11,37 \%$.
\end{abstract}

Kata Kunci: Speed, Agility And Quickness (SAQ), Kelincahan Dan Futsal

\section{PENDAHULUAN}

Olahraga identik dengan tingkat kebugaran atlet, bahkan hampir semua cabang olahraga membutuhkan kebugaran jasmani. Kebugaran jasmani merupakan kemampuan tubuh seseorang untuk melakukan tugas pekerjaan sehari- hari tanpa menimbulakan kelelahan yang berarti dengan cara latihan fisik yang melibatkan komponen kebugaran jasmani dengan metode latihan yang benar (Santoso, 2016).

Futsal merupakan olahraga yang sedang berkembang pesat di kalangan masyarakat, baik di lingkungan pendidikan, perkantoran maupun masyarakat umum. Permainan futsal tidak hanya dijadikan sebagai salah satu olahraga rekreasi, akan tetapi telah menjadi olahraga kompetitif yang dipertandingkan diberbagai event daerah, nasional maupun internasional (Kharisma \& Mubarok, 2020). Pada hakikatnya permainan futsal merupakan "induk" dari olahraga sepakbola karena karakteristik permainan futsal yang tidak jauh berbeda dengan olahraga sepakbola (Setiabudi, 2016). Futsal sendiri merupakan permainan dengan tempo cepat sehingga sangat dibutuhkan kondisi fisik yang baik. Pemain yang mempunyai kondisi fisik yang prima akan cenderung memiliki rasa percaya diri pada saat pertandingan dibandingkan dengan pemain yang tidak mempunyai banyak stamina yang baik akan mudah kehilangan konsentrasinya pada saat pertandingan (Wahyudianto et al., 2020).

Kondisi fisik bagi atlet merupakan hal yang mutlak dan wajib dimiliki oleh seorang atlet dalam cabang olahraga apapun. Kodisi fisik adalah satu kesatuan utuh dari komponen-komponen yang tidak dapat dipisahkan begitu saja, baik peningkatan maupun pemeliharaannya. Artinya bahwa di dalam usaha peningkatan kondisi fisik maka seluruh komponen tersebut harus dikembangkan, walaupun disana-sini dilakukan dengan sistem prioritas sesuai 
Jurnal Kejaora: Jurnal Kesehatan Jasmani dan Olah Raga

ISSN: 2541-5042 (Online)

ISSN: 2503-2976 (Print)

Volume 5 Nomor 2, Edisi November 2020

keadaan atau status tiap komponen itu dan untuk keperluan apa keadaan atau status yang dibutuhkan tersebut (Herpandika et al., 2019).

Kondisi fisik merupakan salah satu komponen yang berpengaruh terhadap prestasi sebuah tim sepakbola selain komponen lain yaitu: keterampilan teknik, taktik, dan mental pemain. Kondisi fisik dalam olahraga sepakbola meliputi: daya tahan (endurance), daya ledak otot tungkai (explosive power), kecepatan (speed), dan kelincahan (agility) (Candra \& Kurniawan, 2020).

Apabila seseorang ingin mencapai sesuatu prestasi optimal perlu dimiliki empat macam kelengkapan yang meliputi: (1) pengembangan fisik, (2) pengembangan teknik, (3) pengembangan mental, (4) kematangan juara (Setiawan et al., 2020). Peningkatan kondisi fisik atlet tentunya membutuhkan latihan yang terprogram dengan baik untuk mencapai sebuah prestasi. Pelatihan merupakan salah satu faktor yang sangat menentukan kedalam mencapai tujuan-tujuan yang telah ditentukan dalam suatu kegiatan olahraga oleh seorang atlet. Pelatihan fisik umum untuk setiap cabang olahraga sama, akan tetapi pelatihan fisik khususnya untuk setiap cabang olahraga berbeda-beda (Wora et al., 2017).

Prestasi olahraga tidak dapat diraih dengan cara instan, dibutuhkan bentuk latihan yang sistematis, terukur, terprogram dan teratur dengan mengikutsertakan sport science, teknologi dan ilmu pengetahahuan yang mendukung (Mardhika, 2017).

Peningkatan komponen kondisi fisik sangat diperlukan dalam setiap cabang olahraga dalam meningkatkan prestasi. Kelincahan merupakan salah satu komponen kondisi fisik yang sangat penting dalam cabang olahraga futsal. Sehingga dengan kelincahan yang baik atlet dapat dengan mudah memainkan permainan futsal dan dapat mencapai prestasi. Dengan adanya penelitian ini diharapkan menjadi bahan evaluasi kepada para pelatih dalam memberikan model dan bentuk latihan kepada atletnya.

\section{METODE}

Jenis penelitian ini adalah eksperimen dengan rancangan penelitian one group pretest-posttest design. Dimana desain ini terdapat pretest sebelum diberikan perlakuan sehingga hasil lebih akurat, karena dapat membandingkan keadaan sebelum perlakuan dann sesudah perlakuan (Sugiyono, 2014). Teknik sampling yang digunakan dalam penelitian ini menggunakan metode matching pairing. Dengan analisis data menggunakan statistik Uji-t.

\section{HASIL DAN PEMBAHASAN}

Deskripsi data pada kelompok eksperimen memberikan gambaran tentang tes awal, tes akhir, rerata dan standar deviasi dari masing-masing variabel kelincahan. Perolehan data dari hasil penelitian kelompok eksperimen dari kelincahan dapat dilihat pada tabel di bawah ini.

Tabel 1. Deskrisi Data Penelitian

\begin{tabular}{ccccccc}
\hline Variabel & Test & $\begin{array}{c}\text { Rata-rata } \\
\text { (means) }\end{array}$ & Stdv & Varians & Max & Min \\
\hline \multirow{2}{*}{ Kelincahan } & Pretest & 11,26 & 0,44 & 0,19 & 10,59 & 12,27 \\
\cline { 2 - 7 } & Posttest & 10,11 & 0,54 & 0,29 & 9,43 & 11,53 \\
\hline
\end{tabular}

Hasil data variabel kelincahan sebagaimana pada tabel 1 di atas, merupakan hasil dari test sebelum dan setelah perlakuan. Pada hasil tabel di atas menunjukkan adanya peningkatan kecepatan yang signifikan setelah diberi perlakuan selama enam minggu. Hal ini dapat dilihat dari rerata tes akhir sebesar 10,11 dan rerata tes awal sebesar 11,26 dengan standart devisiasi untuk pre-test sebesar 0,44 dan post-test sebesar 0,54 . Sehingga selisih dari rerata tersebut menunjukkan adanya peningkatan setelah diberi perlakuan selama pelatihan delapan minggu dan dengan frekuensi tiga kali. 
Jurnal Kejaora: Jurnal Kesehatan Jasmani dan Olah Raga

ISSN: 2541-5042 (Online)

ISSN: 2503-2976 (Print)

Volume 5 Nomor 2, Edisi November 2020

Dengan demikian dari gambar di atas selanjutnya dapat disimpulkan bahwa setelah adanya perlakuan selama enam mingggu dengan program pelatihan speed, agility and quickness (SAQ) dapat memberikan dampak peningkatan kelincahan sebesar $11,37 \%$.

Uji normalitas data dimaksudkan untuk mengetahui normal atau tidaknya suatu data. Sehingga pengujian normalitas data ini sebagai langkah ke proses pengujian statistik inferensial. Statistik inferensial merupakan suatu cara untuk membuat kesimpulan secara keseluruhan berdasarkan data yang dikumpulkan. Dalam hal ini untuk menyimpulkan uji normalitas data secara keseluruhan menggunakan One-Sample Kolmogorov-Smirnov Test. Adapun kriteria pengujian normalitas data adalah :

Tabel 2. Hasil Uji Normalitas Data Kedua Variabel Terikat

\begin{tabular}{lllll}
\hline Variabel & Test & Sig & Ket & Status \\
\hline \multirow{5}{*}{ Kelincahan } & Tes & 0.963 & $\mathrm{P}>$ & \multirow{2}{*}{ Normal } \\
\cline { 2 - 5 } & Awal & & 0,05 & \\
\cline { 2 - 6 } & Tes & 0.697 & $\mathrm{P}>$ & Normal \\
& Akhir & 0,05 & Norm
\end{tabular}

Berdasarkan pada tabel 2 di atas menunjukkan bahwa perolehan data dari kedua variabel terikat yaitu kelincahan memiliki makna bahwa data berdistribusi normal. Hal ini dikarenakan signifikansi ( $p$ ) dari masing-masing kelompok menunjukkan (p) atau sig $>0,05$ yang mengakibatkan $\mathrm{H}_{0}$ diterima. Sehingga dapat disimpulkan bahwa data diambil dari populasi yang berdistribusi normal.

Uji homogenitas ini digunakan untuk memperlihatkan bahwa dua atau lebih kelompok data sampel berasal dari populasi yang memiliki varians yang sama. Untuk keperluan dalam penelitian ini uji homogenitas diperlukan untuk mengetahui kesamaan subjek dari ketiga kelompok. Dalam penelitian ini terdapat dua variabel yang harus diuji untuk homogenitas data yaitu kecepatan dan kelincahan. Adapun kriteria uji homogenitas data sebagai berikut :

Tabel 3. Hasil Uji Homogenitas Varians

\begin{tabular}{|c|c|c|c|c|}
\hline Variabel & Test & $\begin{array}{l}\text { Sig } \\
(P)\end{array}$ & Ket & Status \\
\hline \multirow{2}{*}{ Kelincahan } & $\begin{array}{c}\text { Tes } \\
\text { Awal }\end{array}$ & 0.581 & $\begin{array}{l}P> \\
0,05\end{array}$ & Homogen \\
\hline & $\begin{array}{c}\text { Tes } \\
\text { Akhir }\end{array}$ & 0.509 & $\begin{array}{c}\mathrm{P}> \\
0,05\end{array}$ & Homogen \\
\hline
\end{tabular}

Berdasarkan pada tabel 3 di atas menunjukkan bahwa perolehan data kedua variabel terikat yaitu kelincahan memiliki varians homogen. Hal ini dimaknai oleh karena nilai signifikansi dari masing-masing data menunjukkan taraf signifikansi atau $(p)>$ 0,05 . Sehingga dapat disimpulkan bahwa varians pada kelompok adalah sama atau homogen.

Untuk mengetahui pengaruh program pelatihan speed aqility and quickness dan plyometric, maka langkah pengujiannya menggunakan uji-t yang dalam SPSS disebut sebagai paired t-test. Adapun hasil pengolahan datanya pada tabel di bawah ini.

Tabel 4. Hasil Uji Beda Variabel Dependent pada Kelompok Eksperimen

\begin{tabular}{lllll}
\hline Variabel & Pair & t-hitung & Sig. (2-tailed) & Status \\
\hline Kelincahan & Posttest - Pretest & -8.162 & 0,000 & Berbeda \\
\hline
\end{tabular}

Para pelatih merumuskan dan menerapkan berbagai metode pelatihan untuk memaksimalkan kinerja pemain/atlet. Speed, agility and quickness (SAQ) adalah komponen pelatihan yang paling signifikan dalam keberhasilan pada kecabangan olahraga baik dalam Futsal maupun olahraga lainnya. Peningkatan kemampuan untuk bereaksi dengan cepat, menerapkan kekuatan dengan cepat ke arah yang tepat, dan mengarahkan kekuatan merupakan adalah tujuan utama dari program pelatihan speed, agility and quickness (SAQ). Kelompok program pelatihan speed, agility and quickness (SAQ) menunjukkan perbaikan pada kecepatan dan kelincahan. Kinerja pada kecepatan dan kelincahan kelompok pelatihan speed, agility and 
Jurnal Kejaora: Jurnal Kesehatan Jasmani dan Olah Raga

ISSN: 2541-5042 (Online)

ISSN: 2503-2976 (Print)

Volume 5 Nomor 2, Edisi November 2020

quickness (SAQ) meningkat masing-masing dari pretest ke posttest.

Hasil penelitian yang ditemukan oleh peneliti bahwa mula-mula atlet kesulitan saat mengikuti bentuk pelatihan yang diberikan. Atlet kesulitan dalam mengikuti irama gerakan pelatihan speed, agility and quickness. Tetapi setelah beberapa kali mencoba atlet tidak kesulitan lagi. Untuk itu diperlukan penjejakan atau pengenalan gerakan pelatihan speed, agility and quickness yang akan dilakukan oleh atlet selanjutnya. Hal ini selaras dengan hasil penelitian Chandrakumar \& Ramesh (2015) bahwa pelatihan speed, agility and quickness (SAQ) secara signifikan meningkatkan kecepatan dan kelincahan pemain klub olahraga bulutangkis.

\section{KESIMPULAN}

Dengan demikian dari gambar di atas selanjutnya dapat disimpulkan bahwa setelah adanya perlakuan selama enam mingggu dengan program pelatihan speed, agility and quickness (SAQ) dapat memberikan dampak peningkatan kelincahan sebesar $11,37 \%$.

\section{DAFTAR PUSTAKA}

Candra, A. T., \& Kurniawan, R. A. (2020). Analisis Tingkat Kebugaran Jasmani Pemain Sepak Bola Sekolah Sepak Bola Tanjung Jaya Dan Sekolah Sepak Bola Uddhata. Journal STAND: Sports and Development, 1(1), 27-34.

Chandrakumar, N., \& Ramesh, C. (2015). Effect of ladder drill and SAQ training on speed and agility among sports club badminton players. International Journal of Applied Research, 1(12), 527-529.

https://mkuniversity.ac.in/new/school/ sedu/journal/Physical_Education/Dr.C .Ramesh/1.Effect_of_ladder_drill_and _SAQ_training_on_speed_and_Agilit y_among_sports_club_badminton_pl ayers.pdf

Herpandika, R. P., Yuliawan, D., \& Rizky, M. Y. (2019). Studi Kondisi Fisik Dan Status Gizi Atlet Puslatkot Kota Kediri 2019. Prosiding Seminar Nasional IPTEK Olahraga, 5-8.

Kharisma, Y., \& Mubarok, M. Z. (2020). Analisis Tingkat Daya Tahan Aerobik Pada Atlet Futsal Putri AFKAB Indramayu. PHYSICAL ACTIVITY JOURNAL, 1(2), 125-130. http://jos.unsoed.ac.id/index.php/paju/ article/view/2005/1184

Mardhika, R. (2017). Pengaruh Latihan Resistance Dan Pyometric Terhadap Kekuatan Otot Tungkai Dan Kelincahan Pada Pemain Futsal. 68, 5-12.

Santoso, D. A. (2016). Analisis Tingkat Kebugaran Jasmani Atlet Bolavoli Putri Universitas Pgri Banyuwangi. Kejaora, 1(1), 37-46.

Setiabudi, M. A. (2016). Pengaruh Pelatihan Small Sided Games Terhadap Peningkatan Kapasitas Aerobik Maksimal (Vo 2 Max) Pada Pemain Futsal. Jurnal Kejaora (Kesehatan Jasmani Dan Olahraga), 1(1), 21-31.

Setiawan, W., Setyaningsih, P., Rahmat, L. I., \& Supono. (2020). Training Of Young Badminton Athletes With The Uniba Cup I Championship. GANDRUNG: Jurnal Pengabdian Kepada Masyarakat, 1(2), 49-52. https://doi.org/10.36526/gandrung.v1i 2.939

Sugiyono. (2014). Cara Mudah Menyusun: Sripsi, Tesis, dan Disertasi (2nd ed.). Bandung:Alfabeta.

Wahyudianto, M. Z., Setiawan, I., \& Pratama, B. A. (2020). Pengaruh Latihan Small Side Game Tipe Intermitten Terhadap Kapasitas Aerobik Di Sekolah Sepakbola Satria Muda Lamongan. SPRINTER: Jurnal IImu Olahraga, 1(1), 72-78.

Wora, D., Adiatmika, I. P., Fufu, O., Adiputra, N., Muliarta, M., \& Griadhi, I. P. A. (2017). Pelatihan Zig-Zag Run Lebih Efektif Meningkatkan Kelincahan Menggiring Bola Dari Pada Pelatihan Shutlle Run Dalam Permainan Futsal. Sport and Fitness Journal, 5(2), 1-9. 